\title{
Distribution of Hepatitis C Virus Genotypes: 18-Year Experience in an Academic Center
}

\section{Hepatit C Virüs Genotip Dağılımı: Akademik Bir Merkez, 18 Yıllık Deneyim}

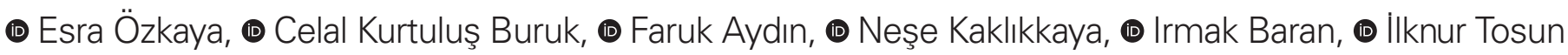 \\ Karadeniz Technical University Faculty of Medicine, Department of Clinical Microbiology, Trabzon, Turkey
}

\begin{abstract}
Objectives: Hepatitis $\mathrm{C}$ virus (HCV) is an important public health problem worldwide. This study examined long-term changes in distribution of HCV genotypes $s$ in HCV-RNA-positive patients in a large population.

Materials and Methods: Following HCV genotype and subtype sequence analysis, the sequence and the reference sequences were compared with the "line probe assay" method or the multiplex amplification methods of 5'UTR and NS5B or only NS5B.

Results: In the study, HCV-RNA positive 670 patients undergoing genotyping were included. Genotype 1 was detected in 603 patients (90.0\%), genotype 3 in $45(6.7 \%)$, genotype 2 in $12(1.8 \%)$, genotype 4 in $6(0.9 \%)$, combined genotypes 1 and 2 in $2(0.3 \%)$, and genotypes 1 and 4 in 2 (0.3\%). Genotypes 5, 6, 7 and 8 were not observed in this study. The most dominant subtypes by years were genotype $1 \mathrm{~b}(82.8 \%)$ and genotype $3 \mathrm{a}(4.5 \%)$. Genotype $1 \mathrm{~b}$ was detected in $63.2 \%$ of patients under $<50$ years of age and in $89.7 \%$ of those $\geq 50$ years of age ( $p<0.001)$, while genotype 3 was determined in $2.0 \%$ of patients aged $\geq 50$ years of age and in $20.1 \%$ of those $<50$ years of age $(p<0.001)$.

Conclusion: This study revealed that changes occurred in the general distribution of HCV genotype and subtypes by years, and that HCV genotype $1 \mathrm{~b}$ was seen at the highest rate, especially in patients over 50 years old.
\end{abstract}

Keywords: Genotype, hepatitis C virus, subtype

\section{ÖZ}

Amaç: Hepatit C virüsü (HCV) kronik hepatit, siroz, hepatosellüler karsinom gibi hastalıklara yol açması nedeniyle önemli bir halk sağlığı sorunudur. Bu çalışmada, geniş bir popülasyondaki HCV-RNA pozitif hastalarda, HCV genotip dağılımında uzun bir dönemdeki değişimin incelenmesi amaçlandı.

Gereç ve Yöntemler: HCV genotip ve subtipleri dizi analizi sonrasında dizinin referans dizilerle karşılaştırılması; "line probe assay" yöntemiyle veya 5'UTR ve NS5B'nin veya sadece NS5B'nin multipleks amplifikasyonu yöntemlerinden biriyle gerçekleştirildi.

Bulgular: Çalışmada HCV-RNA pozitif olup genotiplendirme yapılan toplam 670 hasta yer aldı. Hastaların 603'ünde $(\% 90,0)$ genotip $1,45^{\prime}$ inde $(\% 6,7)$ genotip 3,12 'sinde $(\% 1,8)$ genotip 2 ve 6 'sinda $(\% 0,9)$ genotip 4, 2'sinde $(\% 0,3)$ genotip 1 ve 3 ve yine 2 'sinde $(\% 0,3)$ genotip 1 ve 4 birlikteliği tespit edildi. Çalışmada genotip $5,6,7$ ve 8'e rastlanmadı. Yıllara göre en baskın subtip genotip $1 \mathrm{~b}(\% 82,8)$ idi. Ikinci en sık saptanan subtip ise genotip 3a $(\% 4,5)$ idi. Genotip 1b $<50$ yaş olan hastalarda $\% 63,2$ ve $\geq 50$ yaş olan hastalarda \%89,7 oranında $(p<0,001)$ saptanırken, $\geq 50$ yaş olan hastalarda genotip $3 \% 2,0$ ve $<50$ yaş olan hastalarda ise $\% 20,1$ oranında saptandı $(p<0,001)$

Sonuç: Bu çalışmada HCV genotip 1b'nin en yüksek oranda, özellikle de 50 yaş üzerindekilerde görüldüğü ortaya konmuştur. Anahtar Kelimeler: Genotip, hepatit C virüs, subtip

Özkaya E, Buruk CK, Aydın F, Kaklıkkaya N, Baran I, Tosun I. Distribution of Hepatitis C Virus Genotypes: 18-Year Experience in an Academic Center. Viral Hepat J. 2021;27:118-123.

Address for Correspondence: Esra Özkaya MD, Karadeniz Technical University Faculty of Medicine, Department of Clinical Microbiology, Trabzon, Turkey

Phone: +90 4623775155 E-mail: esraozkaya@ktu.edu.tr ORCID ID: orcid.org/0000-0003-1673-9101 Received: 13.06.2021 Accepted: 30.08 .2021

${ }^{\circ}$ Copyright 2021 by Viral Hepatitis Society / Viral Hepatitis Journal published by Galenos Publishing House. 


\section{Introduction}

The hepatitis $\mathrm{C}$ virus ( $\mathrm{HCV}$ ), a member of the genus hepacivirus from the family flaviviridae, infects an estimated 130-200 million individuals worldwide $(1,2)$. According to World Health Organization figures for 2018, 71.1 million individuals worldwide are infected with $\mathrm{HCV}$, and approximately 475,000 die from the infection every year (3). Since the prevalence of HCV varies among different regions, countries are grouped in terms of the incidence of $\mathrm{HCV}$ infection. Eighty percent of HCV infections are seen in 31 countries. Six countries in particular (China, Pakistan, Nigeria, Egypt, India, and Russia) are host to $50 \%$ of all cases (4). HCV is also an important public health problem with a high probability of chronicization and still with no effective vaccine, that leads to severe liver diseases such as hepatocellular carcinoma and cirrhosis $(2,5)$.

There are eight confirmed HCV genotypes and 86 subtypes to date (4). The distribution of HCV genotypes and subtypes exhibits geographic variations. Genotype 1 is responsible for $44 \%$ of all $\mathrm{HCV}$ infections worldwide, and for $60 \%$ of infections in high and middleincome countries (4). Globally, the leading genotypes are 1a, 1b, 2a, $2 \mathrm{~b}$, and $3 \mathrm{a}$. Approximately one in three genotype 1 infections are seen in East Asia. Genotype 3 infections are more widespread in lower-middle-income countries than in high-income, upper-middleincome, and lower-income countries and constitute $25 \%$ of all HCV infections (4). Approximately 75\% of HCV genotype 3 infections are seen in South Asia. Genotype 4 has been detected more widely in Central Africa and the Middle East, and genotypes 2 and 6 in East Asia (1,4). Genotype 5, 7, and 8 represent less than 1\% of all HCV infections, with several cases emerging from southern and central sub-Saharan Africa (1,4). HCV genotypes have been shown to vary in terms of disease severity, prognosis, and response to antiviral drugs $(4,6)$. Therefore, HCV genotyping is an important component of pre-treatment diagnostic algorithms, especially as it guides the therapeutic regimen process (7). Knowing the genotypes is the most important factor determining the selection of an effective antiviral agent, the length of treatment, and the expected virological response $(6,8)$. A knowledge of regional HCV genotype distributions is therefore essential for the development of international and domestic HCV infection management strategies.

The purpose of this study was to examine the HCV genotype distribution in the previous 18 years among HCV-RNA-positive patients in a broad population.

\section{Material and Methods}

\section{Research Type and Study Group}

HCV genotype results from HCV-RNA-positive blood specimens studied at the Karadeniz Technical University Clinical Microbiology
Laboratory, Turkey, between 2002 and 2019 were evaluated retrospectively. Patients' demographic data were retrieved from the hospital information system.

Specimens from the patients included in the study were investigated in the academic clinical microbiology laboratory of a 960-bed tertiary university hospital in the Eastern Black Sea region of Turkey. The study population consisted of patients infected with $\mathrm{HCV}$, the great majority living in the region (approximate population 2.9 million individuals per year). Six hundred seventy patients were enrolled in the study, the first specimen being evaluated in case of repeated specimens.

The study was approved by Karadeniz Technical University Faculty of Medicine Clinical Research Ethical Committee (approval number: 2020/169).

\section{HCV-RNA Quantitation}

The HCV-RNA load in specimens was determined using bDNA (Branched DNA, HCV 3.0 bDNA assay, Bayer Diagnostics, USA) or one of various real time PCR applications (COBAS ${ }^{\circledR}$ AmpliPrep/ COBAS ${ }^{\circledR}$ TaqMan ${ }^{\circledR}$ HCV test, Roche Diagnostics Corporation, USA, Abbott RealTime HCV Assay, Abbott Molecular Inc., USA, and Bosphore ${ }^{\circledR}$ HCV Quantification Kit, Anatolia Geneworks, Turkey).

\section{HCV Genotyping Procedure}

Following HCV genotype and subtype " 5 'untranslated region (5'UTR)" or "non-structural 5B" (NS5B) amplification and sequence analysis, the comparison of the sequence with reference sequences were studied with either using the "line probe assay" method (INNO-LiPA HCV II, Innogenetics, Belgium) or two different commercial Real-Time PCR kits, by the method of multiplex amplification of the 5'UTR and NS5B (Abbott RealTime HCV Genotype II Assay, Abbott Molecular Inc., USA) or only NS5B (HCV Genotyping Kit v1 Bosphore, Geneworks Anatolia, Turkey).

\section{Statistical Analysis}

Statistical analysis was performed on SPSS version 21 software (SPSS Inc., Chicago, IL, USA). Non-parametric data not conforming to normal distribution at the Kolmogorov-Smirnov test were compared using the Mann-Whitney $U$ test. The chi-square test and Fisher's exact test were employed in the comparison of categorical variables. P-values $<0.05$ were regarded as statistically significant.

\section{Results}

Three hundred fifty-nine (59.6\%) of the 670 patients in the study were men and 311 (46.4\%) were women. The patients' mean age was $58.27 \pm 16.53$ years (minimum-maximum: 4-112). Genotype distributions by gender are shown in Table 1. No significant difference in genotype distribution was observed between the genders $(p=0.461)$

\begin{tabular}{|c|c|c|c|c|c|c|c|c|c|c|}
\hline \multirow{2}{*}{ Gender } & \multicolumn{10}{|c|}{ HCV genotypes n (\%) } \\
\hline & \multicolumn{3}{|l|}{1} & \multicolumn{2}{|l|}{2} & \multicolumn{2}{|l|}{3} & $4^{*}$ & Mixed & Total n (\%) \\
\hline Female & $13(4.2)$ & $9(2.9)$ & $261(83.9)$ & $6(1.9)$ & - & $6(1.9)$ & $11(3.5)$ & $3(1.0)$ & $2(0.6)$ & $311(46.4)$ \\
\hline Male & $10(2.8)$ & $16(4.5)$ & $294(81.9)$ & $5(1.4)$ & $1(0.3)$ & $9(2.5)$ & $19(5.3)$ & $3(0.8)$ & $2(0.6)$ & 359 (53.6) \\
\hline
\end{tabular}




\begin{tabular}{|c|c|c|c|c|c|c|c|c|c|c|}
\hline \multirow{2}{*}{ Year } & \multicolumn{10}{|c|}{ HCV Genotypes n (\%) } \\
\hline & \multicolumn{3}{|l|}{1} & \multicolumn{2}{|l|}{2} & \multicolumn{2}{|l|}{3} & $4^{*}$ & Mixed & Total (n) \\
\hline 2002 & - & - & $5(100.0)$ & - & - & - & - & - & - & 5 \\
\hline 2004 & - & - & $10(90.9)$ & - & - & - & $1(9.1)$ & - & - & 11 \\
\hline 2007 & - & $1(50.0)$ & $1(50.0)$ & - & - & - & - & - & - & 2 \\
\hline 2008 & - & - & $5(100.0)$ & - & - & - & - & - & - & 5 \\
\hline 2009 & - & $2(3.9)$ & $49(96.1)$ & - & - & - & - & - & - & 51 \\
\hline 2010 & $5(5.8)$ & $1(1.2)$ & $72(82.8)$ & $1(1.2)$ & - & $3(3.5)$ & $4(4.6)$ & - & 1 (1.2) (genotip 1b+3a) & 87 \\
\hline 2014 & $2(4.4)$ & $2(4.4)$ & $38(84.4)$ & - & - & $1(2.2)$ & $1(2.2)$ & $1(2.2)$ & - & 45 \\
\hline 2015 & - & $3(11.1)$ & $23(85.2)$ & - & - & $1(3.7)$ & - & - & - & 27 \\
\hline 2016 & $8(11.9)$ & $2(3.0)$ & $52(77.6)$ & $1(1.5)$ & - & $4(6.0)$ & - & - & - & 67 \\
\hline 2017 & $1(1.9)$ & - & $48(90.6)$ & $1(1.9)$ & - & - & $2(3.8)$ & - & 1 (1.9) (genotip $1 b+3 a)$ & 53 \\
\hline 2018 & $1(1.8)$ & $3(5.3)$ & $43(75.4)$ & $1(1.8)$ & - & - & $7(12.3)$ & $2(3.5)$ & - & 57 \\
\hline 2019 & $1(1.9)$ & $3(5.8)$ & $33(63.5)$ & $2(3.9)$ & $1(1.9)$ & $2(3.9)$ & $10(1.9)$ & - & - & 52 \\
\hline Total & $23(3.4)$ & $25(3.7)$ & $555(82.8)$ & $11(1.6)$ & $1(0.2)$ & $15(2.2)$ & $30(4.5)$ & $6(0.9)$ & $4(0.6)$ & 670 \\
\hline
\end{tabular}

Genotype 1 was determined in 603 patients (90.0\%), genotype 3 in 45 (6.7\%), genotype 2 in 12 (1.8\%), genotype 4 in six $(0.9 \%)$, combined genotypes 1 and 3 in two (0.3\%), and genotypes 1 and 4 in two (0.3\%). Genotypes 5, 6, 7, and 8 were not encountered. The most frequently identified subtypes were genotype $1 \mathrm{~b}(82.8 \%)$ and genotype $3 a(4.5 \%)$. Detailed distributions by years of genotypes and subtypes are shown in Table 2.

The mean age of the 603 patients infected with genotype 1 was 59.72 \pm 16.29 years (minimum-maximum: 4-112), compared to $45.26 \pm 12.51$ years (minimum-maximum: 20-77) for patients infected with other genotypes, and the difference was statistically significant $(p<0.001)$. The distribution of HCV genotypes by age is shown in Table 3. Genotype 1b was detected in $63.2 \%$ of the 174 patients aged under 50 and in $89.7 \%$ of the 496 patients aged over 50 ( $p<0.001)$. While mixed genotypes and genotype 4 were encountered in patients aged $\geq 50$, genotype 3 and its subtypes were more common in patients aged $<50$ (20.1\% of patients $<50$ compared to $2 \%$ of patients $\geq 50$ )

Thirty $(4.5 \%)$ patients were foreign nationals, and these patients' home countries and genotypes are shown in Table 4. The most common genotype in these patients was $1 \mathrm{~b}(50 \%)$ followed by genotype $3(40 \%)$ and genotype $2(10 \%)$.

\section{Discussion}

This study adds to the existing literature by determining the distribution of HCV genotypes, an important factor in treatment management, and by evaluating changes in genotype distributions by years in an academic center.
High rates of genotype $1 \mathrm{~b}$ have been reported in European countries, Israel, and Japan, while genotype 1a has more frequently been reported in North America and Northern Europe $(9,10)$. Similarly to other studies from Turkey, the most frequently identified HCV genotype in all years throughout the present study was genotype $1 \mathrm{~b}(82.8 \%)$ (Table 5). HCV genotypes in the study population varied significantly with age. The genotype $1 \mathrm{~b}$ rate among patients under 50 was significantly lower than that among patients over $50(p<0.001)$. This may be due to a decrease with age in infection rates with $\mathrm{HCV}$ genotypes other than genotype $1 \mathrm{~b}$.

In Europe, HCV genotype infections are reported to be mostly seen in women, and at advanced ages, and to be associated with blood transfusions, dental treatment, and nosocomial infections (11). The risk factors and modes of transmission among the patients infected with HVC in the present study are unknown. However, patients ranged in age between 20 and 64, and no gender difference was observed. Globally, genotype 2 is more common in West Africa in particular, and in some regions of South America (12). This clustering is thought to be associated with migration patterns linked to the transatlantic slave trade (12). The distribution rates of genotype 2 across the world are highly heterogeneous, ranging between $0.1 \%$ and $24.5 \%$. In the present study, HCV genotype 2 was detected in $1.8 \%$ (12) of patients, a rate higher than that in Central Europe $(0.1 \%)$, but significantly lower than those in the Asian Pacific (24.5\%), West Africa (23\%), Western Europe (10.8\%), and worldwide (9.1\%) (12).

$\mathrm{HCV}$ genotype 3 is the second most common genotype worldwide, after genotype 1, and is particularly dominant in South Asian countries $(12,13)$. A proportional increase was determined 


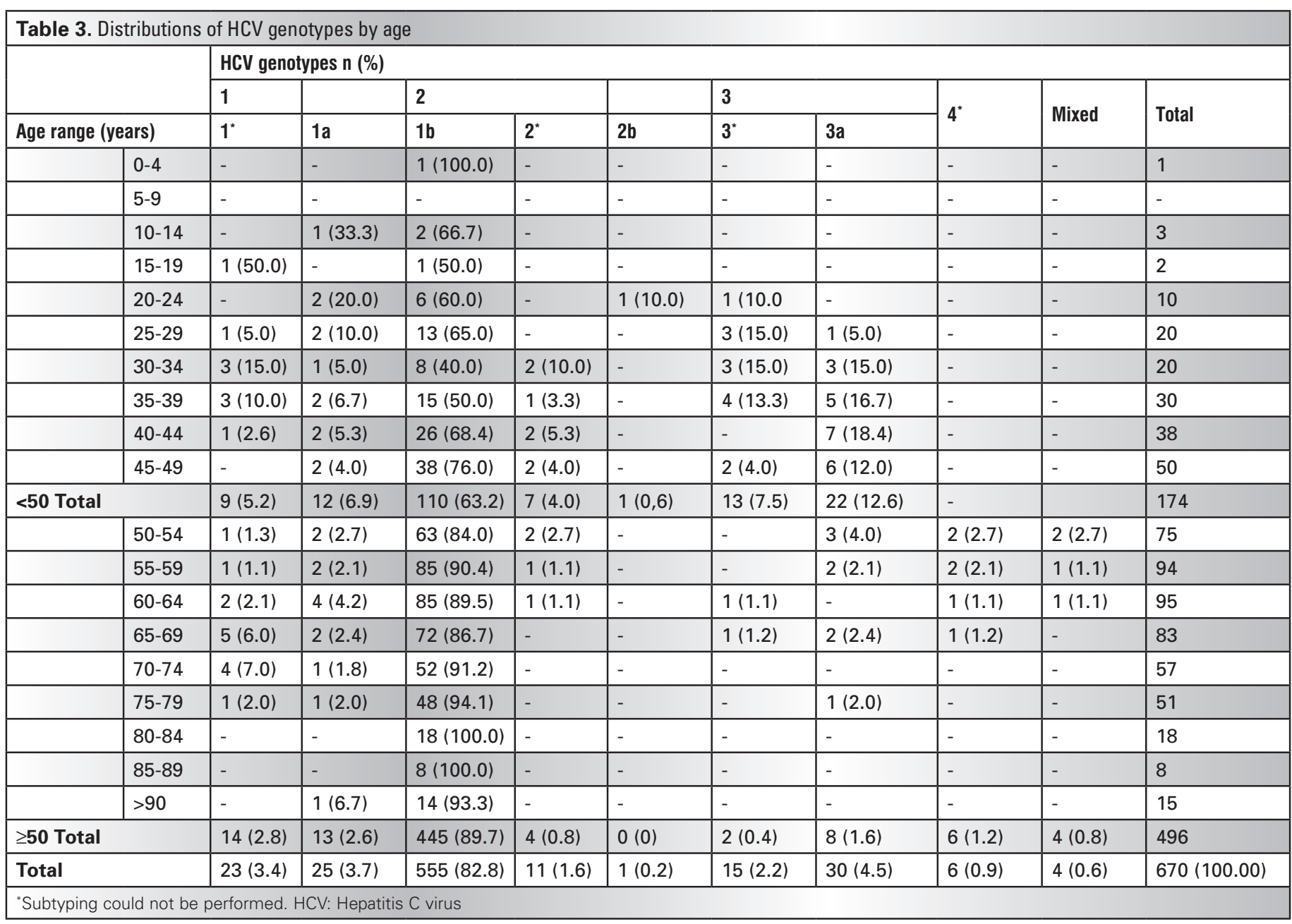

\begin{tabular}{|c|c|c|c|c|c|c|c|c|c|c|}
\hline \multirow[b]{2}{*}{ Country of origin } & \multicolumn{10}{|c|}{ HCV genotypes n (\%) } \\
\hline & $1^{*}$ & $1 \mathrm{a}$ & $1 b$ & $2^{*}$ & $2 b$ & $3^{*}$ & $3 a$ & $4^{*}$ & Mixed & Total \\
\hline Georgia & - & - & $12(60.0)$ & - & - & $1(5.0)$ & $7(35.0)$ & - & - & 20 \\
\hline Iraq & - & - & - & $1(50.0)$ & - & $1(50.0)$ & - & - & - & 2 \\
\hline Russia & - & - & $1(50.0)$ & $1(50.0)$ & - & - & - & - & - & 2 \\
\hline Tajikistan & - & - & $1(100.0)$ & - & - & - & - & - & - & 1 \\
\hline Ukraine & - & - & - & - & - & $1(100.0)$ & - & - & - & 1 \\
\hline Total & - & - & $15(50.0)$ & $3(10.0)$ & - & $4(13.3)$ & $8(26.7)$ & - & - & 30 \\
\hline
\end{tabular}

in genotype 3 after 2010 in the present study. The proportion of patients aged under 50 infected with HCV genotype 3 was significantly higher than that of patients aged over $50(20.1 \%$ and $2.0 \%$, respectively, $\mathrm{p}<0.001)$. It was most frequently observed in the 35-39 age group (30.0\%), and the genotype is more common in males. This variation may be due to reciprocal human mobility such as tourism, education, workforce activities, and marriages, in the community comprising the study population.
Medical procedures without the use of protective measures are the basic risk factor for HCV infection in Middle Eastern and North African countries, and genotype 4 predominates in those countries (65.3\%) (12). Genotype 4 is the most frequently seen genotype in Syria, at $59.0 \%(2,3,13,14)$. Turkey has a long historical relationship with these countries for reasons such as religious pilgrimages, migration, and tourism (2). In the present study, HCV genotype 4 began being detected after 2012, and this may have 


\begin{tabular}{|c|c|c|c|c|c|c|c|c|c|c|c|c|c|c|}
\hline \multirow{2}{*}{ Study } & \multirow{2}{*}{ Year } & \multirow{2}{*}{ No. (n) } & \multicolumn{12}{|c|}{ HCV genotype distribution (\%) } \\
\hline & & & 1 & $1 a$ & $1 \mathrm{~b}$ & 2 & $2 b$ & 3 & $3 a$ & 4 & $4 a$ & 5 & 6 & Mixed \\
\hline Bozdayi et al. (19) & $1997-2000$ & 365 & - & 11.0 & 84.0 & 3.0 & - & 1.0 & - & 1.0 & - & - & - & - \\
\hline Cil et al. (18) & $2004-2005$ & 22 & & 22.7 & 72.7 & & & 4.5 & & & & & - & \\
\hline İba Yilmaz et al. (20) & $2008-2010$ & 46 & - & - & 100.0 & - & - & - & - & - & - & - & - & - \\
\hline Celik et al. (21) & 2010 & 178 & - & 9.0 & 88.2 & 1.1 & - & 1.7 & - & - & - & - & - & - \\
\hline Karslıgil et al. (22) & 2011 & 51 & - & 9.8 & 78.4 & 7.8 & - & 2.0 & - & 2.0 & - & - & - & - \\
\hline Kayman et al. (2) & $2010-2011$ & 218 & 62.4 & 2.3 & 60.1 & 4.6 & - & - & - & 33 & - & - & - & - \\
\hline \multirow{2}{*}{ Oztürk et al. (23) } & 2010-2012 & 315 & - & 3.5 & 55.2 & 14.6 & - & 26.0 & - & 0.6 & - & - & - & - \\
\hline & 2010-2012 & 324 & - & 0.3 & 86.7 & 9.3 & - & 0.9 & - & 2.8 & - & - & - & - \\
\hline Sağlik et al. (10) & $2009-2013$ & 422 & 83.4 & 14.7 & 63.3 & 3.5 & 0.9 & - & 11.1 & 1.6 & - & - & - & 0.2 \\
\hline Çekın et al. (5) & $2011-2013$ & 148 & 8.8 & 12.8 & 60.8 & 4.1 & - & 11.5 & - & 2 & - & - & - & - \\
\hline Akar et al. (24) & $2012-2013$ & 53 & 96.2 & 3.8 & 50.9 & 1.9 & - & - & - & 1.9 & - & - & - & - \\
\hline Tezcan et al. (25) & 2013 & 236 & 3.8 & 1.7 & 84.7 & 2.1 & & & 4.2 & - & 0.8 & - & - & - \\
\hline Altuğlu et al. (26) & 2013 & 535 & 93.3 & 12.9 & 80.4 & 1.5 & - & 3.7 & - & 1.5 & . & - & - & - \\
\hline Caliskan et al. (27) & 2010-2014 & 313 & 51.7 & - & - & 1.3 & - & 46.0 & - & 1.0 & - & - & - & - \\
\hline Cirit et al. (16) & 2011-2015 & 312 & 69.6 & & & 14.1 & & 3.8 & & 10.3 & & 1.6 & - & 0.6 \\
\hline Çetin Duran et al. (14) & 2015-2016 & 119 & 71.4 & 12.6 & 58.8 & 7.6 & & 16.8 & & 3.4 & & 1 & - & \\
\hline \multirow{3}{*}{ Kulah et al. (15) } & $2007-2016$ & 6.0 & 1.7 & 5.5 & 79.8 & 3.3 & 0.8 & - & 5.7 & 0.5 & - & - & 0.2 & 1.8 \\
\hline & 2007-2016 & 336 & 23.0 & 3.6 & 82.8 & 1.2 & 1.2 & 0.3 & 3.3 & 1.5 & & 0.3 & 0.6 & 1.8 \\
\hline & 2007-2016 & 675 & 5.2 & 17.2 & 58.4 & 1.6 & 1.2 & 7.3 & 5.3 & 1.6 & & 1.2 & 0.2 & $5(0.7)$ \\
\hline Kirdar et al. (17) & 2011-2016 & 286 & 90.2 & - & - & 2.1 & - & 5.9 & - & 1.4 & - & - & - & 0.35 \\
\hline $\begin{array}{l}\text { Calgin and Cetinkol } \\
\text { (28) }\end{array}$ & 2016-2018 & 165 & 2 & 5.6 & 91.4 & & & 2.5 & & 0.5 & & & - & \\
\hline
\end{tabular}

been the effect of the arrival in Turkey of refugees from Syria. HCV genotype 4 was reported in as many as $32.0 \%$ of chronic hepatitis $\mathrm{C}$ in one study, and since the timing coincided with times of labor force migration, the authors thought that it might have been carried by people moving to these areas (2). In the present study, however, genotype 4 was detected in only eight patients, and a more reliable interpretation when the future distribution is revealed.

The detection of HCV genotype co-presence facilitates ideal patient follow-up and increases the effectiveness of antiviral drug therapies (15). In recent years, mixed type HCV genotype reports have been issued more frequently in Turkey $(15,16,17)$. One multicenter study from Turkey determined a mixed genotype prevalence of $1.3 \%(15)$. Genotype $1 \mathrm{~b}$ and 4 was the most frequently seen mixed genotype combination in that study, while the lowest rates were reported for $2 b+2 c, 1 a+3,1 a+4,2+3$, and $3+4$ genotype combinations (15). High mixed genotype rates of $15.6 \%$ in Taiwan, $19.0 \%$ in the Dominican Republic, and $15.7 \%$ in Iraq have been reported. The highest rate of patients with mixed genotypes among European countries was reported in Serbia, at 8.5\%. The closest rates to those of the present study were recorded from Venezuela at $0.7 \%$, Mexico at $0.7 \%$, and the United States of America at $0.5 \%$ (13).

Analysis of the 30 foreign national patients in this study revealed that the most common genotypes, in descending order, were 1, 3, and 2, and no other genotypes were detected. Approximately $60 \%$ of these patients were Georgians, and Georgians also represent the majority of foreign patients with genotypes $1 \mathrm{~b}$ and 3a. Genotype $1 \mathrm{~b}$ was observed at a lower rate, $50 \%$, in this patient group compared to the data for Turkey, while rates for genotype 2 and 3 were higher, at $10 \%$ and $40 \%$, respectively. Consistent with the present study, analysis of HCV genotype distributions in Russia, Georgia, and the Turkic republics has shown that genotype $1 \mathrm{~b}$ is dominant, followed by genotype 3, and then by genotype 2 (13). These data indicate that genotype distributions can change over time, in both our own region, in Turkey, and worldwide, especially as travel becomes easier.

Since the HCV is an RNA virus with high genetic variability, no effective vaccine is available. Therapeutic protocols and novel direct-acting antiviral drug studies are based on genotypes and subtypes $(3,18)$.

\section{Study Limitations}

The limitation of our study is that the absence of information about the transmission routes due to the retrospective design of the study.

\section{Conclusion}

The findings of the present study revealed a time-dependent change in the general distribution of HCV genotypes and subtypes, and that HCV genotype 1b was observed at the highest rate across the years, particularly among patients over 50 . Since HCV genotypes can be affected by social and cultural diversity, it is essential that the data be updated at specific intervals. In addition, determining changes in epidemiological data will serve as a useful guide for the development of vaccines and novel antiviral agents. 


\section{Ethics}

Ethics Committee Approval: The study was approved by Karadeniz Technical University Faculty of Medicine Faculty Clinical Research Ethical Committee (approval number: 2020/169).

Informed Consent: Retrospective study.

Peer-review: Externally peer-reviewed.

\section{Authorship Contributions}

Surgical and Medical Practices: E.Ö., C.K.B., F.A., N.K., I.B., I.T., Concept: E.Ö., C.K.B., F.A., N.K., I.B., I.T., Desing: E.Ö., C.K.B., Data Collection or Processing: E.Ö., C.K.B., Analysis or Interpretation: E.Ö., C.K.B., F.A., N.K., I.B., I.T., Literature Search: E.Ö., C.K.B., Writing: E.Ö., C.K.B., N.K., I.B., I.T.

Conflict of Interest: No conflict of interest was declared by the authors.

Financial Disclosure: The financial support of the study was provided by the researchers.

\section{References}

1. Bouacida L, Suin V, Hutse $V$, Boudewijns $M$, Cartuyvels $R$, Debaisieux L, De Laere E, Hallin M, Hougardy N, Lagrou K, Oris E, Padalko E, Reynders M, Roussel G, Senterre JM, Stalpaert M, Ursi D, Vael C, Vaira D, Van Acker J, Verstrepen W, Van Gucht S, Kabamba $\mathrm{B}$, Quoilin S, Muyldermans G. Distribution of HCV genotypes in Belgium from 2008 to 2015. PLoS One. 2018;13:e0207584.

2. Kayman T, Polat C, Ergör G, Abacioğlu YH. Characterization of HCV genotype 4d infections in Kayseri, Turkey. Turk J Med Sci. 2015; 45:547-552.

3. Sallam M, Batarseh R, Natsheh A, Abbadi J, Al-Fraihat E, Yaseen A, Kaddomi D, Khamees N, Mahafzah A, Şahin GÖ. An update on hepatitis $\mathrm{C}$ virus genotype distribution in Jordan: a 12-year retrospective study from a tertiary care teaching hospital in Amman. BMC Infect Dis. 2019;20:3.

4. Spearman CW, Dusheiko GM, Hellard M, Sonderup M. Hepatitis C. Lancet. 2019;394:1451-1466.

5. Çekın Y, Gür N, Çekın AH, Altuğlu I, Yazan Sertöz R. Investigation of hepatitis $\mathrm{C}$ virus genotype distribution in patients with chronic hepatitis C infections in Antalya Training and Research Hospital, Turkey. Mikrobiyol Bul. 2014;48:484-490.

6. Buruk CK, Bayramoğlu G, Reis A, Kaklıkkaya N, Tosun I, Aydın F. Determination of hepatitis $C$ virus genotypes among hepatitis C patients in Eastern Black Sea Region, Turkey. Mikrobiyol Bul. 2013;47:650-657.

7. Vince A, Židovec Lepej S, Bingulac-Popović J, Miletić M, Kuret S, Sardelić S, Vrakela IB, Kurelac I. Distribution of hepatitis C virus genotypes and subtypes in Croatia: 2008-2015. Cent Eur J Public Health. 2018;26:159-163.

8. Karabulut N, Alacam S, Yolcu A, Onel M, Agacfidan A. Distribution of hepatitis $\mathrm{C}$ virus genotypes in Istanbul, Turkey. Indian J Med Microbiol. 2018;36:192-196.

9. Selek MB, Baylan O, Karagöz E, Özyurt M. Changes in hepatitis C virus genotype distribution in chronic hepatitis $C$ infection patients. Indian J Med Microbiol. 2018;36:416-421.

10. Sağlik I, Mutlu $D$, Öngut $G$, Inan $D$, Öğünç $D$, Can Sarinoğlu R, Özhak Baysan B, Gültekin M, Çolak D. Distribution of hepatitis C virus genotypes among patients with chronic hepatitis $\mathrm{C}$ infection in Akdeniz University Hospital, Antalya, Turkey: a five-year evaluation. Mikrobiyol Bul. 2014;48:429-437.

11. Petruzziello A, Marigliano S, Loquercio G, Cacciapuoti C. Hepatitis $\mathrm{C}$ virus (HCV) genotypes distribution: an epidemiological update in Europe. Infect Agent Cancer. 2016;11:53.

12. Messina JP, Humphreys I, Flaxman A, Brown A, Cooke GS, Pybus $\mathrm{OG}$, Barnes $\mathrm{E}$. Global distribution and prevalence of hepatitis $\mathrm{C}$ virus genotypes. Hepatology. 2015;61:77 87

13. Gower E, Estes C, Blach S, Razavi-Shearer K, Razavi H. Global epidemiology and genotype distribution of the hepatitis $\mathrm{C}$ virus infection. J Hepatol. 2014;61(Suppl1):S45-57.

14. Çetin Duran A, Kibar F, Çetiner S, Yaman A. Determination of hepatitis $\mathrm{c}$ virus genotype and HCV infection transmission routes in Cukurova University Medical Faculty Hospital. Turk Hij Den Biyol J. 2017;74:201-210.

15. Kulah C, Altindis M, Akyar I, Gokahmetoglu S, Sayiner A, Kaleli I, Fidan I, Altuglu I, Aydin F, Topkaya A, Us T, Findik D, Ozdemir M, Oztürk E, Ulger ST, Karsligil T, Cekin Y, Aksaray S, Uzunoglu E, Aktas O, Uslu H, Cetinkol Y, Gureser AS, Ece G, Toptan H, Koroglu M, Comert $\mathrm{F}$. The prevalence of mixed genotype infections in turkish patients with hepatitis c: a multicentered assessment. Clin Lab. 2019;65:485-490.

16. Cirit OS, Uzala Mızraklı A, Vurupalmaz $Y$, Gümüş $H H$, Özturhan $H$, Barış A. Genotyping Distribution of Hepatitis C Virus in Şanlıurfa Province and Effect of Syrian Patients. Viral Hepat J. 2019;25:62-66.

17. Kirdar S, Aydin N, Tiryaki Y, Ertugrul B, Coskun A, Bilgen M. Dynamics of HCV epidemiology in Aydin province of Turkey and the associated factors. APMIS. 2018;126:109-113.

18. Cil T, Ozekinci T, Goral V, Altıntaş A. Hepatitis C virus genotypes in the southeast region of Turkey. Turkiye Klinikleri J Med Sci. 2007; 27:496-500.

19. Bozdayi AM, Aslan N, Bozdayi G, Türkyilmaz AR, Sengezer T, Wend U, Erkan O, Aydemir F, Zakirhodjaev S, Orucov S, Bozkaya H, Gerlich W, Karayalçin S, Yurdaydin C, Uzunalimoğlu O. Molecular epidemiology of hepatitis $B, C$ and $D$ viruses in Turkish patients. Arch Virol. 2004;149:2115-2129.

20. İba Yilmaz S, Erol S, Özbeks A, Parlak M. Distribution of viral genotypes and extrahepatic manifestations in patients with chronic hepatitis C in Eastern Turkey. Turk J Med Sci. 2015;45:70-75.

21. Çelik C, Bakıcı MZ, Kaygusuz R, Ertürk R. The searching of HCV genotyping distributions in the region of Sivas. Viral Hepatit J. 2010;16:106-110.

22. Karslıgil T, Savaş E, Savaş MC. Genotype distribution and 5'UTR nucleotide changes in hepatitis C virus. Balkan Med J. 2011;28:232236.

23. Oztürk AB, Doğan UB, Oztürk NA, Ozyazici G, Demir M, Akin MS, Böngöl AS. Hepatitis C virus genotypes in Adana and Antakya regions of Turkey. Turk J Med Sci. 2014;44:661-665.

24. Akar T, Aynıoğlu A, Dındar G, Babür T. Contribution to determination of hepatitis $\mathrm{C}$ virus genotypes in Black Sea region: data from single high volume center in Zonguldak, Turkey. Mikrobiyol Bul. 2014;48:518-520.

25. Tezcan S, Ulger M, Aslan G, Yaraş S, Altıntaş E, Sezgin O, Emekdaş G, Gürer Giray B, Sungur MA. Determination of hepatitis C virus genotype distribution in Mersin province, Turkey. Mikrobiyol Bul. 2013;47:332-338.

26. Altuğlu I, Sertöz R, Aksoy A, Gürsel D, Tüzüner U, Günşar F. Possible transmission risks and genotype distribution of hepatitis $C$ virus infection in Western Turkey. Turk J Gastroenterol. 2013;24:349-355.

27. Caliskan A, Kirisci O, Ozkaya E, Ozden S, Tumer S, Caglar S, Guler $\mathrm{SA}$, Senol H. Distribution and predominance of genotype 3 in hepatitis c virus carriers in the province of Kahramanmaras, Turkey. Hepat Mon. 2015;15:e25142.

28. Calgin MK, Cetinkol Y. Hepatitis C virus genotype distribution in Ordu province. J Clin Anal Med. 2019;10:372-375. 